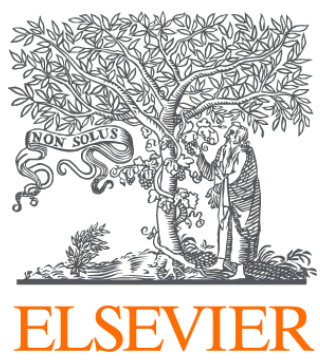

Since January 2020 Elsevier has created a COVID-19 resource centre with free information in English and Mandarin on the novel coronavirus COVID-

19. The COVID-19 resource centre is hosted on Elsevier Connect, the company's public news and information website.

Elsevier hereby grants permission to make all its COVID-19-related research that is available on the COVID-19 resource centre - including this research content - immediately available in PubMed Central and other publicly funded repositories, such as the WHO COVID database with rights for unrestricted research re-use and analyses in any form or by any means with acknowledgement of the original source. These permissions are granted for free by Elsevier for as long as the COVID-19 resource centre remains active. 


\section{Letter to the Editor}

\section{Observations on disinfectant performance}

\section{Sir,}

One of the cornerstones for infection control must be adequate disinfection of environmental surfaces, particularly high-touch surfaces. This becomes even more important during a pandemic.

The recent review by Kampf et al., entitled 'Persistence of coronaviruses on inanimate surfaces and their inactivation with biocidal agents' [1], claimed that 'data obtained with benzalkonium chloride at reasonable contact times were conflicting. Within $10 \mathrm{~min}$ a concentration of $0.2 \%$ revealed no efficacy, whereas a concentration of $0.05 \%$ was quite effective'.

In the case of benzalkonium chloride, the reference cited for the demonstration of no efficacy dated from 1989. In that paper [2], a disinfectant solution with an active ingredient concentration of $0.2 \%$ appeared to show no efficacy against the enveloped human coronavirus, whereas it showed remarkable activity ( $>5.12$ log reduction) against a non-enveloped coxsackie virus.

A second study cited by Kampf et al. [1], this time dating from 1998 , showed a $>3.7$ log reduction in coronavirus in $10 \mathrm{~min}$ using a $0.05 \%$ solution of a pharmacopeial grade of benzalkonium chloride (i.e. not a formulated disinfectant product) [3].

In a third study cited by Kampf et al. [1], a more contemporary formulated benzalkonium chloride disinfectant, when tested at a concentration of $0.5 \%$, gave a $>6.13 \mathrm{log}$ reduction in coronavirus in $30 \mathrm{~min}$ in both clean and dirty conditions [4]. Unfortunately, this result was not included, whereas the test results obtained from various ethanol-based hand rubs from the same study were included in the review.

The use of quaternary-ammonium-based disinfectants to deactivate severe acute respiratory syndrome coronavirus-2 (SARS-CoV-2) has been recommended by several jurisdictions. For example, the US Environmental Protection Agency has provided a list of suitable disinfectant products for use against SARS-CoV-2 (List N) [5].

As of $16^{\text {th }}$ April 2020, List $\mathrm{N}$ contains 370 recommended products. Of these, $171(48 \%)$ products contain quaternary ammonium active ingredients alone, and a further 33 products contain quaternary ammonium salts formulated with at least one other class of active ingredient. By way of comparison, only 56 products containing sodium hypochlorite as their active ingredient are listed, along with only five products listing ethanol as their active ingredient.

It is acknowledged that many of the products on List $\mathrm{N}$ will not have direct test data against SARS-CoV-2, but all products on the list have been shown to be effective against either human coronavirus or non-enveloped viruses, which are recognized to be more resistant to disinfection than enveloped viruses (of which SARS-CoV-2 is an example) [6].

In the case of citations of the age under question, we note considerable reservations. Disinfectant products in most modern health systems are required to meet minimum standards of performance on statutory test methods that have been agreed through robust peer review. These statutory testing regimes then take over from peer review as the achievements are no longer regarded as novel. The absence of peer review does not mean that these products do not work sufficiently, and reference to raw material alone becomes an obsolete consideration in terms of predictable performance against the test protocols.

We are deeply concerned that the selective quotation of material from the underlying references provides the reader with what amounts to a biased view of the material. The review by Kampf et al. [1] appears to move the reader to an intended product grouping rather than allowing the data to provide the essential information required for a scientifically based conclusion.

Finally, we would like to address the apparent lack of peer review for the review by Kampf et al. [1], which was accepted for publication on the same day it was received. In a pandemic situation, timely publication of relevant material is to be welcomed. However, if that material is drawing conclusions on disinfectant efficacy based on a very narrow dataset, peer review must surely form an essential part of the publication process.

\section{Conflict of interest statement}

Both authors are employees of Whiteley Corporation, a manufacturer of cleaning products and disinfectants.

\section{Funding sources}

None.

\section{References}

[1] Kampf G, Todt D, Pfaender S, Steinmann E. Persistence of coronaviruses on inanimate surfaces and their inactivation with biocidal agents. J Hosp Infect 2020;104:246-51.

[2] Wood A, Payne D. The action of three antiseptics/disinfectants against enveloped and non-enveloped viruses. J Hosp Infect 1998;38:283-95.

[3] Saknimit M, Inatsuki I, Sugiyama Y, Yagami K. Virucidal efficacy of physico-chemical treatments against coronaviruses and 
parvoviruses of laboratory animals. Jikken Dobutsu Exp Anim 1988;37:341-5.

[4] Rabenau HF, Kampf G, Cinatl J, Doerr HW. Efficacy of various disinfectants against SARS coronavirus. J Hosp Infect 2005;61:107-11.

[5] US Environmental Protection Agency. List N: disinfectants for use against SARS-CoV-2. Washington, DC: US EPA; 2020. Available at: https://www.epa.gov/pesticide-registration/list-n-disinfectantsuse-against-sars-cov-2 [last accessed April 2020].

[6] Prince HN, Prince DL. Principles of viral control and transmission. In: Block SS, editor. Disinfection, sterilization and preservation. $5^{\text {th }}$ ed. Philadelphia: Lippincott Williams \& Wilkins; 2001. p. 543-72.

\author{
T. Glasbey ${ }^{\mathrm{a}, *}$ \\ G. Whiteley \\ aWhiteley Corporation, Tomago, Australia \\ ${ }^{\mathrm{b}}$ Whiteley Corporation, North Sydney, Australia \\ Laverick Avenue, Tomago, NSW 2322, Australia.
}

* Corresponding author. Address: Whiteley Corporation, 19-23

E-mail address: trevor.glasbey@whiteley.com.au (T. Glasbey)

Available online $x x x$ 